\title{
Research on the Model of Developing Cross - Border E-commerce Talents under the Belt and Road
}

\author{
Dingli Gao ${ }^{1}$, Wei Peng ${ }^{2}$ \\ ${ }^{1}$ Chengdu Normal University, Chengdu, Sichuan, 611130 \\ ${ }^{2}$ Sichuan Provincial Machinery Research and Design Institute, Chengdu, Sichuan, 610063
}

Keywords: Cross-border E-commerce, Talents Training, The Belt and Road

\begin{abstract}
The "Belt and Road" Initiative and "Internet +" have become the general framework and action plan for the country's future economic development, and cross-border e-commerce has become a breakthrough point. This paper analyzes the background of cross-border e-commerce talent training, and conducts research and exploration on the training objectives, specifications and curriculum system of cross-border e-commerce professionals and the practice of cross-border e-commerce talent cultivation.
\end{abstract}

\section{Introduction}

September 20, 2017 Premier Li Keqiang chaired a State Council executive meeting calling for the construction of a new comprehensive cross-border e-commerce pilot zone that will extend the cross-border e-commerce transitional transition policy to the end of 2018 to develop cross-border e-commerce, promote international trade liberalization, and facilitate Innovation and format innovation are conducive to transforming the mode of foreign trade development and enhancing overall competitiveness. Since 2014, the favorable policies of cross-border e-commerce have been promulgated by counties and places intensively and piloted in cross-border e-commerce cities. Ali speed, Amazon, Jingdong and other companies have settled in cross-border e-commerce. According to the "Research Report on Cross-border E-commerce Talents in China" conducted by Ali Research Institute, $85.9 \%$ of enterprises consider the gap in cross-border e-commerce talent serious. The survey shows that small businesses have relatively more demand for e-commerce professionals and are more likely to recruit specialist personnel. They also hope that these professionals have a combination of knowledge and skills. In 2015, the new professional directory will introduce international business (cross-border e-commerce) and professional training programs urgently need to be explored and explored. Taking the direction of international business (cross-border e-commerce) of Hebei Institute of Industrial Technology as an example, this paper studies the professional training objectives, specifications, curriculum system, and time-based entrepreneurship to cultivate talents in cross-border e-commerce for the Beijing-Tianjin-Hebei region [1].

\section{Cross-border e-commerce talent training skills requirements}

The scope of business of cross-border e-commerce is global, so there is a significant difference between the logistics of different countries in the modes of transportation, information communication and risk compared with domestic logistics. Therefore, cross-border e-commerce professionals need to grasp the cross-border procurement management, supply chain management knowledge, customs clearance, customs inspection, tax rebates and other rules. Choose the best way to import and export goods and track international logistics and follow up with international settlement and international insurance [2].

The common point with traditional e-commerce network customer service is that cross-border e-commerce customer service is still mainly in the form of online customer service; however, it is completely different from the traditional online customer service, which is closely related to the object characteristics of cross-border e-commerce customer service. Cross-border e-commerce 
customer service objects from over 200 countries and regions in the world mainly foreign consumers. The traditional cultures, customs and habits of different countries, ethnic groups and regions in the world are very different. Therefore, based on the traditional skills of service providers for e-commerce, it is also necessary to understand the cultural backgrounds of various countries and conduct cross-border e-commerce customer service operations in a more targeted manner Interact, communicate, and prevent business disputes well [3].

Cross-border e-commerce business posts daily work and customer service are often used to foreign languages, the need for staff positions have a high level of listening, speaking, reading and writing foreign language comprehensive ability in general, mainly in English dealing with correspondence between countries or regions, in English Introduce products and services on the internet platform and communicate and communicate with customers in various countries in fluent English. Even expanding the cross-border e-commerce market in the emerging countries, but also need to use a small country-specific language in order to more authentic expression and communication.

Cross-border e-commerce network marketing talent is different from the traditional e-commerce network marketing personnel more complicated, that is, need to have the international market research, analysis and forecasting capabilities, for different target countries or regions accurately network marketing activities planning, Sns operations, data collection and analysis, to cater to the buying habits of consumers in countries or regions, so as to better develop the international market on the network.

Cross-border e-commerce professionals need to accurately grasp the cross-border e-commerce data management and operation of the road, so as to better improve the conversion rate. Specifically, cross-border e-commerce data management needs to have a number of business operations skills, including the maximum optimization of CTR and conversion rate for different countries or regions, data selection, store data analysis, wireless data Analyze, improve product exposure and use data to drain and other skills [4].

With the increasing number of small and micro businesses participating in cross-border e-commerce through large and small platforms, cross-border e-commerce professionals need to be innovative in being familiar with the business rules of the industry under the background of "mass entrepreneurship and innovation" And entrepreneurial thinking, comply with the trend of cross-border e-commerce industry segmentation, breaking through the bottleneck in cross-border e-commerce development, go abroad, enter the international market and broaden the path of innovation and entrepreneurship.

\section{Cross-border e-commerce talent training objectives and curriculum system research}

The purpose of international business (cross-border e-commerce) is to cultivate the basic line of supporting the party, develop all-round moral, intellectual, physical and aesthetic education, acquire basic theoretical knowledge and specialized knowledge, and have the necessary operation in cross-border e-commerce platform. Business, website promotion and other professional post group of the actual work of the basic ability and basic skills to adapt to cross-border e-commerce, foreign trade industry, service and management needs of the first line, with good professional ethics and innovative and pragmatic spirit of high-quality technical talent [5].

Understand the humanities quality and basic knowledge of public culture, such as political thoughts, social and situation policies; Understand the basic rules and basic norms of market operation; Master the knowledge of economics, management science and financial analysis; Master tools of English communication and business office software ; Master the cross-border e-commerce platform operations, international trade practices, network marketing and planning, logistics procurement and management, shop design and operation and maintenance expertise.

Familiar with the operation, maintenance and day-to-day management of cross-border platforms such as AliExpress; Familiar with marketing promotion tools and promotion methods of each platform to formulate practical promotion programs. Familiar with import and export trade, warehouse management, logistics, cross-border e-commerce operation; Have a certain English 
writing and communication skills; Have a certain sense of innovation and basic entrepreneurial ability; Have good social communication and interpersonal skills; Have strong access to knowledge and Knowledge transfer ability [6].

Have a high sense of social responsibility, love the motherland, diligence and dedication, the pursuit of excellence; have a good cultural accomplishment; have good physical and mental qualities, optimistic, proactive; abide by professional ethics, emphasis on integrity, with high professional knowledge and business Ability, and work style of unity and cooperation, there is a sense of entrepreneurial innovation.

Professional basic courses are mainly to cultivate the basic knowledge and quality of business professional, including professional introduction, international trade, economics, business English listening, speaking, management foundation, shop art, business office software applications, marketing and other courses. Professional core courses mainly cultivate students' professional core competence including cross-border e-commerce operation ability, cross-border e-commerce marketing capability and foreign trade business capability, etc. Generally, they include 4-6 courses, international trade practices, cross-border e- Border e-commerce (B2B), cross-border e-commerce marketing, business English correspondence, internships and other courses.

\section{Cross-border e-commerce talent training strategy}

The goal is to cultivate the direction of training programs must be clear before the implementation of training objectives, cross-border e-commerce talent training is to cultivate cross-border e-commerce application-oriented talents, which e-commerce professionals training mode is different. Cross-border e-commerce personnel training needs to strengthen students 'English proficiency, and students' English should have certain listening, speaking and writing abilities. Cross-border e-commerce needs to go abroad and require colleges and universities to train advanced, applied talents. Modular course teaching is divided into modules teaching courses, each module to complete certain functions, but also for students to apply for jobs. In the process of module division, it is based on the ability of students' occupational positions. The curriculum is close to the actual job, achieving internship and zero employment. Each course has a corresponding practice platform. Students can practice through the practice platform to improve their practical abilities to meet the needs of actual jobs. Nowadays, colleges and universities all attach importance to students' abilities of innovation and entrepreneurship. While learning professional skills, they also cultivate students' abilities of innovation and entrepreneurship, improve students' comprehensive qualities, develop complex talents for enterprises, require students to understand foreign trade, computer technology, network technology, marketing Strategy, English and other capabilities, in line with the needs of modern cross-border e-commerce business people.

To improve students 'actual working ability, we must conduct school-enterprise cooperation and jointly run the school, which is the main way to solve the problem of students' ability to work. Now colleges and universities are actively exploring school-enterprise cooperation in running schools to enhance students' practical ability. In order to develop professional colleges and universities, we must deepen the cooperation between schools and enterprises so that teachers and enterprises go to school to undertake certain teaching tasks and realize the real cooperation between schools and schools. In the process of teaching, teachers are generally led by the project-based pedagogy, the introduction of real projects in enterprises, allowing students to complete one of the tasks, changing the traditional teaching mode, the project of teaching method is based on the students as the main character of the class, the teacher is the project Organizers and teachers build a teaching platform so that students can actively display themselves on the platform to enhance students 'actual working ability, encourage students to complete the project teaching, cultivate students' practical ability and meet the needs of cross-border e-commerce enterprises for talents.

Entrepreneurship education is to train students important education, the establishment of cross-border e-commerce venture studio is the development of e-commerce industry needs, but also the needs of social development. Colleges and universities set up entrepreneurial studios according to different occupations of the enterprises. Students join the corresponding studios according to 
their own interests. The studios cooperate with the corresponding enterprises to undertake the projects. With the real platform, real products and real foreign trade flow, students are encouraged to cultivate their entrepreneurial and innovative consciousness. Improve students 'ability to innovate and start a business, enhance their awareness of innovation, improve students' overall accomplishment and cultivate applied talents required by enterprises.

The traditional test papers test is not conducive to test the overall strength of students, therefore, should be properly adjusted assessment methods. To cultivate high-level cross-border e-commerce talents and assess students' ability with test scores is too one-sided and should be eliminated. This part of the students who set up their own shops and start their own businesses should be considered more. Written examination only part of, if the students succeed in business or get good grades, should be as a professional ability test. A single assessment model is very unfavorable for cultivating cross-border e-commerce talents and should be promptly improved. The sum of the test scores of the theoretical test and the result of the practical operation is the student's real ability level. For most students, they pay too much attention to the written test scores and pull down practical skills so that their learning skills and practical skills are not good. In order to improve this situation, the number of released products, product quality, sales performance, profits and other indicators can be used as assessment indicators. To assess students, it is more appropriate.

\section{Conclusions}

The traditional e-commerce talent can only be qualified for traditional e-commerce jobs, and cross-border e-commerce talent in post capacity and competency conditions have new requirements. This is not only to meet the needs of economic globalization, but also to meet the needs of the development of cross-border e-commerce. Under such circumstances, vocational colleges should shoulder their own responsibilities and cultivate talents with a solid professional e-commerce level and strong intercultural communication skills. In the process of cultivating cross-border e-commerce talents, colleges and universities should base on the goals and requirements of cross-border e-commerce talents training, build a curriculum system in a reasonable way, create an all-round practice platform for cross-border e-commerce innovation and entrepreneurship education, apply appropriate assessment methods and To set up a cross-border e-commerce teacher team with high professional quality and improve the quality of cross-border e-commerce education in universities and enhance the professionalism of cross-border e-commerce professionals so as to promote the steady development of cross-border e-commerce industry.

\section{Acknowledgements}

Fund Project: "Cross-border E-commerce Innovation and Entrepreneurship Education Reform" co-sponsored by the Ministry of Education for Cooperation in Industry and Education, No.201701042077

\section{References}

[1] Liu Yuling. Talents Cultivation Model of Polytechnic E-commerce Majors in Education and Industry Cooperation, School-enterprise Cooperation [J]. Huiquan Market Herald, 2016,05: 69-70.

[2] Li Wei, Du Wei. Cross-border E-commerce Talent Cultivation Model in Higher Vocational Colleges in Ethnic Minority Regions Research [J]. Inner Mongolia Education (Vocational Education Edition), 2016,06: 19-20.

[3] Kong Yuan. Innovation and Practice of Combination of Production and Teaching Based on Internet Thinking [J]. Altar, 2015, 08: 62-65.

[4] Sun Congzhong. "Internet +" under the background of cross-border e-commerce talent in vocational colleges "Trinity Body "training mode [J]. Journal of Hubei Adult Education Institute, 2015,06: 14-18. 
[5] Li Ping. On the entrepreneurship and employment education and vocational training of e-commerce professionals[J]. E-commerce, 2011,11: 77-78 +81.

[6] Fan Lingli. "Trinity" to create practical e-commerce professionals - Jiangxi Central Habitat Institute of Vocational Career School as an example [J]. Business Story, 2016,09: 129. 